\title{
Methodical Approaches to Staff Performance Assessment
}

Vodolazhskaya E.L.

Kazan Federal University, Institute of Management, Economics and Finance, Kazan, 420008, Russia

Email: leonid2204@rambler.ru

Pratchenko O.V.

Kazan Federal University, Institute of Language, 420008, Kazan, Russia

Doi:10.5901/mjss.2015.v6n3p685

\begin{abstract}
The article describes the structure of the system of Human Resources management of the company; it is proved that the development and improvement of job descriptions is a strategic direction of anti-crisis Human Resource management; the review of alternative methods for assessing the staff performance is presented; the integrated methodology that allows to use the selective approach to the problem of inclusion of workers of the organizations with different qualities and labor characteristics into the employment system, is proposed.
\end{abstract}

Keywords: Human Resource Management of the company, planning and marketing of staff, job description, organizational structures of HR management, staff performance assessment.

\section{Introduction}

Human Resource Management is a set of targeted functional actions of management team of the company, trade union and other public organizations, as well as heads and experts of departments, which basically includes the following: to determine the personnel requirements in accordance with the purpose, objectives and possibilities of the organization; recruitment, planning of work with the staff (recruitment and selection of personnel, employee displacement, personnel placement and assignment by departments and working places, deployment of staff); analysis of potential and assessment of personnel; motivation and stimulation of labor; staff rotation, its movement in the management system, career path; development of personal and collective qualities of personnel, advanced training, further education, competence enhancement, accumulation of experience; motivation and stimulation of career development of staff, creation of favorable conditions for efficient work, social partnership, social security of personnel during work and after retirement.

The works of the foreign authors: A. Maslow, M.Mescon, M.Albert, F. Khedouri [2, 3, 6, 12], as well as of the domestic authors: V.R.Vesnin, A.Ya.Kibanov, E.I. Kholostova, E.V.Maslov, E.I.Komarov and A.I.Voytenko and others are the theoretical basis of this work.

\section{Methodology}

In case of anti-crisis HR management it is expected to carry out not only the formal organization of HR management, but also to involve the effect of other socio-psychological and moral factors using the democratic style of management, careful attitude to human needs, taking into account his individual characteristics, and so on.

Global changes, crisis in social, economic, political and spiritual spheres of Russia expand opportunities - and also create serious restrictions for every employee, the stability of his existence and growth. In such circumstances, crisis HR management is intended to take into account 0 a whole range of issues on adaptation of an employee to more complicated external and internal conditions of operation and development of the organization. Special attention should be paid to the analysis of motivational attitudes, the ability to form them and to direct in accordance with the challenges of the organization. This should also include the problem of interaction of the heads of the organization with trade unions and employment service to ensure the security of employment of personnel, the development of new approaches to the priority of values $[1,11,13]$.

New tasks cannot be successfully solved by traditional employment services. That is why the service of HR 
management are created in many - mainly large -organizations. The system of anti-crisis HR management is a set of subsystems of general management and a number of functional subsystems specialized in the implementation of homogeneous functions, as well as connections between them. The subsystem of the general management of the organization manages the organization as a whole, management of functional and production units. The head (manager) of the organization, the director and his deputies, heads of functional and production departments, their deputies, masters, foremen perform the functions of this subsystem.

\section{Results}

Analysis of advanced domestic production and foreign organizations showed that a scientifically grounded set of relatively independent functional subsystems, such as the recruitment management subsystem; Personnel employment management; Protection of labor subsystem; Management of personnel skill level development, career management; Management of social development and social security of staff; subsystem of Development of organizational structure of management; subsystem of Legal support of HR system; Information support of HR management subsystem should be part of the HR management system as a part of the overall system (Fig. 1). It is necessary to take into account that the organizational structure of the HR management system depends on the size of the organization, its geographic location, the type of business and many other factors. In small and medium-sized companies one subsystem can perform the functions of several functional subsystems, and in pre-crisis and crisis conditions of activity, even in large organizations some subsystems may be abolished and other systems with a set of new features are created, other structural and functional transformations are also possible.

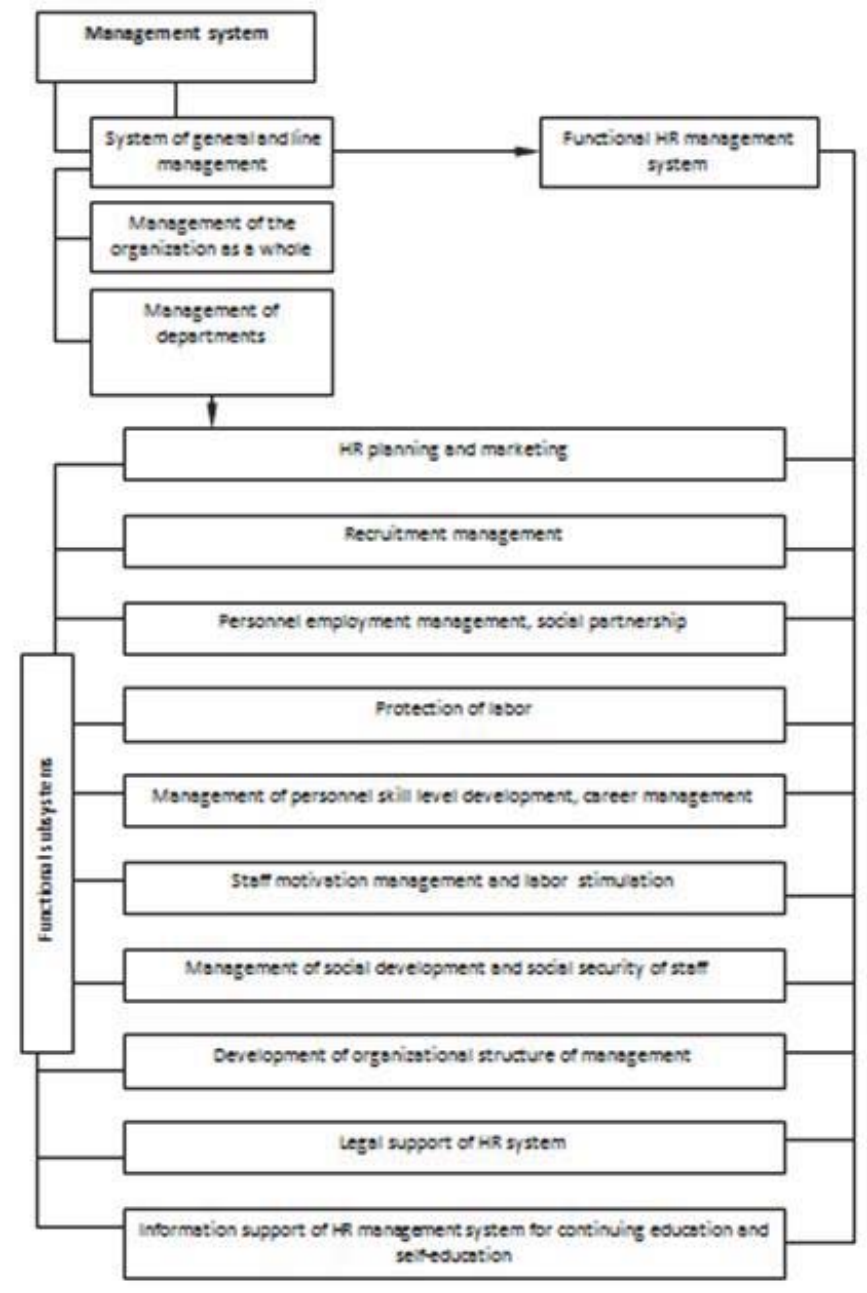

Fig.1. Approximate composition of the personnel management system 
Development and improvement of job descriptions, i.e. definition of a set of qualities of a potential employee who applies for this position, is a special strategic direction of anti-crisis HR management. Professional standards that take into account future needs for personnel of this or that qualification and profession and that may arise in connection with the focus of organization on the new development strategy, should be in the basis of job descriptions, or models of professions. The concept of sustainable development of anti-crisis management, including HR management, encourages and even makes the leaders of the organization focus on strategic, prospective business areas of work with personnel, such as constant mass retraining and (or) advanced training of staff of the organization in connection with transition to new innovative technologies; rejuvenation of personnel by attracting young specialists and encouraging the early retirement of employees who do not "fit" in the new system of requirements and who are not able to master modern methods of work; development of important principles and methods of employment of people in case of their mass layoff; attraction of different specialists for participation in organization management, and so on [9].

Effective use of personnel marketing is a necessary and important strategic direction of the system of anti-crisis HR management. This process is provided by a number of both well-known, as well as new ways: search of prospective first-year students of high schools and colleges: these students should get the opportunity to work in the organization during training practices and holidays with scholarships at the expense of the resources of the organization, support in production and pre-diploma practices; in preparation for graduation paper presentation on interpretation of bottlenecks in the enterprise; cooperation with the public employment service; the use of private firms specialized in selection and training of managers and other staff; interaction with organizations who deal with staff leasing, i.e. sent employees ad interim, "for hire"; organization of prognostic research on training and retraining of skilled workers of the organization.

Formation of appropriate reliable organizational structure in enterprises is a modern and relevant task of anti-crisis HR management. Mastering the new, modernization management technologies is impossible without mastering the basis of the organizational-structural approach that gives the integral understanding of processes of functioning and development of different types of organizations with the account of psychological and socio-economic mechanisms of human behavior in conditions of complicated crisis situations. The analysis showed that four basic types of organizational structures of personnel management are perspective in Russia: integral, business, bureaucratic, participatory (Table 1)

Table 1. Perspective types of organizational structures of personnel management

\begin{tabular}{|c|c|c|c|}
\hline Type of organizational structure & Form of management & Control lever & Spheres of goal determination \\
\hline Integral & Collectivist & Authority & Vested interests \\
\hline Business & Market & Money & Maximum profit \\
\hline Bureaucratic & Bureaucratic & Power & Will of authorities \\
\hline Participation & Democratic & Law & $\begin{array}{c}\text { Interests of law-abiding majority with } \\
\text { obligatory observance of rights of minority }\end{array}$ \\
\hline
\end{tabular}

In one organization there can be several "local" structures: one structure prevailing in the organization, and the structure of its parts - levels, departments, professional, national, age and other groups. These different substructures can coexist under the roof of one general structure.

Four types of forms of management (FM) and corresponding levers of control, as well as spheres of goal determination, are highlighted in the foreign literature devoted to management. In polystructural organizations there are such administrative forms that allow to find various solutions of problems. For example, in case of conflict, the participants can appeal to the universally accepted norms of behavior (FM - collectivist), and to the profit motives (FM - market), and to attitudes of the authorities (FM - bureaucratic), and to the legitimate opinion of the majority of stakeholders (FM Democratic). Experience shows that the formation of the appropriate organizational structure is complex and requires constant attention from the side of top leaders of personnel management system $[4,5]$.

The study shows that at the present time basically four methods of evaluation of staff effectiveness - scoring, SEPO, IAAW and others - are mainly used in theory and practice of management.

The scoring method of staff effectiveness is based on the following. Evaluation of staff is carried out by means of a specific list of economic, social and institutional indicators selected by the methods of expert estimation and correlation analysis and characterizing the final results of the operational performance of the enterprise, the labor and social activities of staff. To do this, the economic stimulation to achieve results with the lowest cost resources and high quality of products, labor and management is introduced. The process of comparison of various economic and social indicators with the account of their importance is implemented in the integrated indicator of personnel effectiveness using weighting coefficients determined by the method of expert assessments and rank correlation. Then the integrated performance 
indicator is calculated as the sum of scores with reduction to the percentage scale of measurements (100 points). As a result, the comparability of quantity and quality of labor in production and management, as well of various business units of enterprises, is provided. Total integrated indicator can be calculated by summing the partial performance indicators that reflect the results of production, the use of resources, social activities of the organization and efficiency of staff. Partial indicators are determined by the performance results of economic and social indicators by multiplying the percent of their performance by the weighting coefficients. The weighting coefficient indicates the relative importance of the economic and social indicator in the general set of performance indicators. The value in scores reflects "contribution" of a particular partial indicator in the efficiency of performance of the enterprise staff.

Method of SEPO (score of efficiency of performance of the organization) is based on determination of the socioeconomic development trends of the enterprise of any organizational-legal form, its effectiveness in terms of achievement of the production, economic and social goals. In the simplified form it is the calculation of efficiency of the enterprise staff for a specified period of time [10]. Then the performance efficiency of the enterprise for a specific period is determined by the numerical value of the overall index of efficiency that characterizes the value of the result achieved with respect to the goals of activity. Value of the SEPO indicator is based on the assessment of the level of achievement of final results of the enterprise, efficient use of resources, social development of staff. The SEPO method helps to determine efficiency of performance of enterprises and organizations, as well as of their structural units in a quarter, year, five years. SERO allows to sum up competition results and to distribute profits among the structural units of enterprises.

Integral assessment of administrative work (IAAW) is designed to determine the contribution of a specific unit of the enterprise (workshop, division, department, service, office, group, laboratory) in the final results of the company [7, 8]. It allows to summarize the results of the competition of departments, to organize the rewarding of employees on the basis of economic activity, taking into account their personal contribution, to mobilize the staff of departments for performance targets, to improve the labor and operational discipline. IAAW is the detailed version and development of SEPO in relation to enterprise departments [7, 8]. Economic, social and institutional indicators divided into three main groups (basic, additional and supplementary) constitute the basic framework of IAAW. The most significant indicators reflect the specific character of work of particular structural units and job management of staff and are presented in the form of statistical reporting. Supplementary indicators characterize social efficiency of the staff. They are contained in the operational reporting and are the same for all subdivisions. The core list and nomenclature of IAAW indicators is determined by the methods of technical-economic analysis, surveys, expert assessments, correlation-regression analysis based on successive logic iterations. The above definitions, statements, practices and procedures allow to conclude that the methodology that would unite all the above and allow to make a simple, clear and transparent analysis and assessment of the company's staff, would be very useful for experts (for example, HR manager).

This study allowed us to propose the integrated methodology for assessing the personnel of the company. The problem is that the quality indicators (quality groups), which applicants are compared by, are numerous (Table 2), and candidates - yielding to competitors by some of them - surpass them by other qualities.

Table 2. List of key indicators of IAAW

\begin{tabular}{|l|}
\hline $\begin{array}{l}\text { Sufficient knowledge and skills in management of the company and competence in questions of production technology of the } \\
\text { industry, in which the company belongs to }(W 1)\end{array}$ \\
\hline Ability to reasonable initiative, reasonable decision-making and forecasting (W2) \\
\hline Ability for the analysis of results of the main activities of subordinate staff and competitors (W3) \\
\hline $\begin{array}{l}\text { Exactingness to staff, knowledge of their capabilities and shortcomings, the ability to use the strengths of employees and to } \\
\text { neutralize the negative features (W4) }\end{array}$ \\
\hline $\begin{array}{l}\text { Determination, self-confidence, the ability to highlight the important things in a variety of tasks; informal, creative approach, self- } \\
\text { control and ability to work in a stressful situation(W5) }\end{array}$ \\
\hline Knowledge of laws and other legislative documents related to the main activities of the company (W6) \\
\hline Ability to plan your work and work of subordinates, ability for adaptive management (W7) \\
\hline Accuracy and personal example in work (W8) \\
\hline
\end{tabular}

In this connection, CEO recognized that it is necessary to resort to mathematical methods of support of managerial decision. The method of solving the problem of choice on the set of options by various indicators (BOF Method) is very convenient for this purpose. Algorithm for solving this problem can be divided into several stages:

1) ranking (division) of properties (Table 2$)$ by importance of $\left(R_{\mathrm{j}}\right)$ according to personal preferences of decisionmaking person (DMP); 
2) determination of the weighting coefficient of every indicator $\left(C_{j}\right)$, norm setting of weighting coefficients of indicators $\left({ }^{C_{j}^{*}}\right)$;

3) ranking of candidates (options) in accordance with preferences of DMP by every indicator $\left(R_{j i}\right)$;

4) determination of specific weighting coefficients of variants (applicants) by every indicator and norm setting of the results obtained $\left(C^{i}\right)$;

5) calculation and justification of the overall index for every option (applicant): $\overline{W_{i}}=\sum j C_{j}^{*} C_{j}^{i}$;

6) identification of the maximum result of the better option by the optimal criterion (determination of the applicant with the highest overall index value).

Let the importance of indicators corresponds to the position of indicators in Table 2 (W1 - the most important; W2 - the least important), and positions of candidates, corresponding to figures in Table 3.

Table 3:

\begin{tabular}{|c|c|c|c|}
\hline WJ & B1 & B2 & B3 \\
\hline W1 & 2 & 3 & 3 \\
\hline W2 & 2 & 1 & 1 \\
\hline W3 & 3 & 2 & 2 \\
\hline W4 & 3 & 1 & 2 \\
\hline W6 & 3 & 1 & 1,5 \\
\hline W7 & 1,5 & 3 & - \\
\hline W8 & 3 & 1 & 1 \\
\hline
\end{tabular}

$B 1=0,259 ; B 2=0,362 ; B 3=0,379$.

\section{Statements}

Thus, the estimate of the real labor potential of employees allows to use selective approach to the problem of inclusion into the system of employment of workers of the organization of different levels of working ability at different stages of their life cycle. Differentiated approach based on the account of the labor potential of the organization, allows to use the substantial part of the labor potential more effectively, to identify and obtain additional labor forces.

\section{References}

Averianov, B.A., Bagautdinova, N.G., Sarkin, A.V. Estimation of manufacturing enterprise development risks in process of operational activity // World Applied Sciences Journal, 27(13), 2013, 202-206.

Baird, Lloyd, and Meshoulam, Ham Managing Two Fits of Strategic Human Resource Management. Academy of Management Review, vol. 13, Ли /, p.p. 116 - 128.

Bowen, David E, and Greiner, Larry Moving from Production to Service in Human Resource Management. Organizational Dynamics, Summer 1986, p.p. 1 - 16.

Butler, John, Ferris, Gerald, and Napier, Nancy Strategy and Human Resources Management. Soth-Western Publishing, Cincinnati, Ohio, 1991.

Ceriello, Vincent Human Resource Management Systems. Lexington, New York, 1991.

Drucker, Peter Goodbye to the Old Personnel Department. The Wall Street Journal, May 22, 1986, P. 16.

Fitz-enz, Jac Human Value Management: The Value -Adding Human Resource Management Strategy for the 1990s. Jossey-Bass, SanFrancisco, 1990.

Safiullin L.N., Shigabieva A.M., Mazitov V.M., Saipullaev U.A. Some methodological foundation of an innovation theory. Life Science Journal 2014; $11(6 s): 388-391$.

Harrod R.F. Theory of imperfect completition revised. - N.Y.: Economic Essays, 1952.

Human Resource Management: Evolving Roles and Responsibilities. Bureau of National Affairs, Washington, D.C., 1988.

Samuelson P. Economics: An Introductory Analysis. New York, 1948.

Bulnina I.S. International legal standards of the bar activity and its domestic security (using the example of the Russian Federation and France. Life Science Journal 2014; 11(6s): 469 - 472.

Sarkin, A.V., Bagautdinova, N.G., Averianov, B.A. Development of science-intensive strategy in machinery-building company in contemporary Russia// World Applied Sciences Journal, 27(13), 2013, 24-28.

Shuller, Randall Repositioning the Human Resource Function: Transformation or Demise. Academy of Management Executive, vol. 4, \# 3 P.P. $49-60$. 
Walker, James Human Resource Strategy, Mc-Graw Hill, Inc. 1992.

Ulesov D.N., Shigabieva A.M., Safiullin L.N., Shaidullin R.N. Essential features of small and medium business. Life Science Journal 2014; $11(6 s): 392-395$.

Askhatova L.I., Bulnina I.S. Quality-of-life (QOL) improvement as a strategic resource of sustainable social and economic development of a region. Life Science Journal 2014 ; 11(6s): 354-357. 